\title{
THE ROLE OF ECONOMIC EVALUATION IN AGRICULTURAL RESEARCH
}

\author{
Stanisław Krasowicz, Full Professor ${ }^{1 *}$; Mariusz Matyka, $\mathrm{PhD}^{2^{* *}}$ \\ Department of Systems and Economics of Crop Production, Institute of Soil Science and Plant Cultivation \\ - State Research Institute in Puławy \\ ${ }^{*}$ https://orcid.org/0000-0003-3949-1444 \\ ${ }^{* *}$ https://orcid.org/0000-0001-6269-1175
}

\begin{abstract}
On the example of the Institute of Soil Science and Plant Cultivation - State Research Institute in Puławy, the scope and importance of economic assessment in agricultural research are presented.

As sources of information, IUNG-PIB reports and reports as well as selected publications were used. It was found that economic assessment enables and facilitates the selection of solutions offered in agricultural practice. Its scope is constantly expanding. It also plays an important role in decision-making processes related to the selection of the management system and a specific variant of production technology on the farm. It also allows explaining many changes and tendencies in agriculture under the influence of the Common Agricultural Policy.
\end{abstract}

Key words: economics, evaluation, role, agricultural research, major problems JEL codes: A11, Q10

\section{INTRODUCTION}

The transition to a market economy system, globalization processes, a wide acceptance of the concept of sustainable development in Western Europe, high dynamics of changes in economic conditions and European integration processes, as well as expectations of agricultural advisory and practice caused changes in agriculture, including a change of priorities and criteria evaluation of agricultural research results. These factors contributed to the development of new directions of agricultural research. For many years, the ultimate goal of agricultural research was to maximize production and profit, and the problems of the impact of agriculture on the environment were not taken into account.

According to Adamowicz (2006) and Harasim, Krasowicz and Matyka (2014), sustainable agriculture is a concept that goes far beyond the traditional treatment of this sector of the economy. Sustainable development is aimed at harmonizing social, economic and environmental goals that lead to an increase in the quality of life in the present, while maintaining the possibility of satisfying human needs in the future.

The concept of sustainable development supports the importance of optimal use of basic agricultural

\footnotetext{
${ }^{1}$ Corresponding author: Czartoryskich 8, Puławy, Poland, sk@iung.pulawy.pl, +4881 4786700

${ }^{2}$ Corresponding author: Czartoryskich 8, Puławy, Poland, mmatyka@iung.pulawy.pl, +4881 4786801
} 
production factors and pay attention to ecological aspects. However, the transition to the market economy system has additionally contributed to the growing importance of economic assessment in agricultural research in the field of production organization and technology. At the same time, these changes determined the role and scope of economic assessments in research institutes conducting agricultural research, in large part with a practical dimension. Economic and organizational studies are conducted in these units. They concern the economics of production directions, the effectiveness of technology and the assessment of various management systems, and the assessment of the regional diversification of agriculture and rural areas.

The aim of the study is to present the role of economic assessment in agricultural research, on the example of the Institute of Soil Science and Plant Cultivation in Puławy. This evaluation takes into account a number of research topics of great practical significance connected with various levels of agricultural production management. It is a derivative of the Institute's scientific interests. The directions of economic evaluation at IUNG-PIB are derived from the scientific interests of the institute's employees. The main of these directions, from the point of view of economic evaluation, include:

- efficiency of agrotechnical operations and treatments as well as production technologies;

- crop rotation with a different proportion of cereals;

- possibilities of sustainable development of farms with various agricultural production directions;

- different farming systems;

- agricultural and rural areas development strategies;

- possibilities of biomass production for energy purposes;

- regional diversification of agriculture.

It is worth emphasizing that the economic and organizational research at IUNG-PIB has a long tradition and refers to the achievements of scientific institutions that have been operating in Puławy since 1862. Since 1998, these studies have been carried out by the Department of Systems and Economics of Crop Production.

\section{EVALUATION OF THE EFFICIENCY OF PRODUCTION TECHNOLOGY AND CROP ROTATION}

Institute of Soil Science and Plant Cultivation - State Research Institute in Puławy offers agricultural practice, based on the results of years of research, agronomic recommendations and production technology of cereals, fodder crops, energy crops, tobacco and hops. The recommended technologies vary in the level of intensity and take into account the diverse economic situation of different groups of farms, as well as the specificity of agriculture in the regions. In addition, they are aimed at obtaining products with a quality, desirable by the industry and consumers, that meet the criteria for safe food for human and animal health. In recent years, the scope of economic assessment in IUNG-PIB research has considerably expanded.

The earliest research began on the economic evaluation of cereal production technology, including such elements of agrotechnology as fertilization and plant protection. This assessment was simplified, as it concerned only direct costs, and sometimes only selected elements. It was found that from the point of view of agricultural income, the partial criterion of labour intensity is of great importance. This constituted the basis for recommending technologies and their variants depending on the diversification of farm labour force resources. These technologies represented various types of production intensification.

The economic evaluation of cereal production technology required constant improvement and enrichment of the methodology as well as extending it with new criteria and indicators. It was also necessary solution to methodological issues. An example of this is the proposal to evaluate plant production technologies as part of crop rotation. It was considered more reliable and comprehensive. An important premise of this trend of economic research is the increase in the share of cereals in the structure of sowings (Statistics Poland, 2018). The economic assessment of crop rotation with different cereal share was of great practical importance. It pointed to the possibility and rationality of applying, under certain 
organizational and economic conditions, changes made only to cereals, referred to as multi-species cereal monocultures. The tendency to specialize in the production of technologically similar plants, i.e. cereals and rapeseed, is particularly pronounced in northern and western Poland (Statistics Poland, 2018).

Consistent enrichment of technological recommendations with a simplified economic assessment, contributed to the objectification of assessments and the development of opinions among farmers and advisers on the desirability and importance of economic calculation in making decisions regarding the choice of plant production technology, and even more widely in farm management.

\section{ECONOMIC EVALUATION OF VARIOUS FARMING SYSTEMS}

Production technologies are derivatives and elements used in the practice of farming systems. The economic evaluation determines the value of individual systems, alongside production and environmental indicators.

As a result of the study work on the comparison of integrated, ecological and conventional systems, the methodology for the analysis and evaluation of agricultural systems in Polish conditions was developed. This methodology is based on the assumption that the assessment of agricultural systems should be made at the level of a farm or a group of farms, treated as an organic whole, and thus in a systemic way. This assumption refers to the view accented in literature. According to Manteuffel (1981): "There is not an abstract agricultural system. Agriculture understood as a production system always takes the form of a farm".

Interest in evaluating different farming systems is also based on the assumption that analysis is necessary taking into account the conditions in the country and the region, and uncritical reliance on foreign research results may lead to opinions and views that are inadequate to the real realities of Polish agriculture. It was found that the ecological system may be a chance to increase the profitability of farms, provided that the development of the organic food market and the growth in demand for organic products. It is also necessary to include in the economic calculation the existing support system for organic farms.

\section{ASSESSMENT OF SUSTAINABILITY OF PRODUCTION IN FARMS}

The factor causing the extension of the scope of the economic assessment was the change of the research subject within the framework of IUNG-PIB statutory activity. The currently implemented program of scientific and research activity "Sustainable development of crop production and management of agricultural areas of Poland", resulted in the necessity of combining the production and ecological assessment with the economic one. The implementation of the IUNG-PIB long-term program, aimed at supporting activities in the field of protection and rational use of agricultural production space in Poland and management of the quality of agricultural raw materials, also contributed to the growing importance of economic assessment in agricultural analyses.

The criteria and economic indicators have found, among others, application in the assessment of the sustainability of production in farms with various habitat conditions and production specialization. The purposefulness of their application resulted from the essence of sustainable development and the necessity to look for indicators that allow for a synthetic assessment of the farm, its internal organization and links with rural areas.

When assessing the level of production sustainability, indicators reflecting dependencies and feedbacks between plant and animal production as well as between the production and household farm of the agricultural family are taken into account.

It was found that the basic factors determining the possibility of sustainable development of a farm are the area and quality of agricultural land. The research allowed for general assessment. 
The natural, organizational and economic conditions determine the possibilities of sustainable development of farms. The natural and organizational conditions determine primarily the intensity of the organization of plant and animal production, which is a derivative of the diversity of sown structure and livestock density. Economic determinants of agricultural production, resulting from existing price relations, determine primarily the intensity of management, measured by the level of material inputs and costs per 1 ha of utilization agricultural area.

The possibility of sustainability production with different objectives is also evaluated depending on the direction of production specialization. In general, it was found that farms specializing in milk production, as well as mixed farms, implemented the principles of sustainable development. Pig farms did not comply with these rules, due to ecological criteria, while farms specializing in crop production due to economic criteria.

An important direction of economic research at IUNG-PIB is also the assessment of the regional diversification of agricultural production, the intensity of the organization, use of agricultural potential, set-aside of land and agricultural competitiveness. In these studies by using the methods of multivariate analysis, the impact of different groups of conditions on regional diversification was assessed. The statement that the regional differentiation of agriculture is determined to a greater extent by economic and organizational than natural and agrotechnical factors. Important problems are also: assessment of the regional differentiation of changes in the land management in Polish agriculture after European integration, and assessment of the possibilities of implementing the Common Agricultural Policy in various regions of Poland. These assessments required consideration of economic aspects and interdisciplinary cooperation. Their results are the basis for perfecting cooperation with consulting.

The development of agriculture in less-favoured areas is an important trend of economic evaluation. In regions prone to drought, as well as in problematic and specific regions in which agricultural development faces a number of systemic and economic constraints. The economic assessment also concerns the possibility of multifunctional development.

\section{EVALUATION OF THE SOCIO-ECONOMIC DETERMINANTS OF BIOMASS PRODUCTION FOR ENERGY PURPOSES}

Recent years have brought new challenges and problems decisive for the importance of economic assessment. Examples are biomass production as a source of renewable energy. According to Nalborczyk (2005), the development of agricultural energy requires the analysis of elements of the future system; including the economic, environmental and social indicators. "In the first place, the work will focus on the optimization of biomass production under different conditions. Particular emphasis will be placed on improving the economic and energy efficiency of production, minimizing negative ecological effects and assessing socio-economic benefits".

IUNG-PIB is conducting research on the assessment of production possibilities, development and implementation of plants cultivation technology for energy purposes, as well as on the use of other renewable energy sources. From the point of view of these studies, it is important to indicate the possibility of land use rationalization and the indication of social and economic factors determining the possibilities of using an alternative, which is plant cultivation for energy purposes. IUNG-PIB research shows that it is necessary to look at the problem of biomass production for energy purposes and adapt the proposed solutions to the existing natural and economic and organizational conditions.

In addition, these studies show that the cultivation of energy crops requires knowledge and high organizational efficiency. IUNG-PIB analyses indicate that in the situation of a relatively lower education of people living in rural areas, the level of professional knowledge and organizational skills may become one of the important barriers on the road to the development strategy of renewable energy. It 
should also be emphasized that all decisions regarding the cultivation of energy crops and the selection of specific technologies should be supported by an economic calculation. In addition, due to changes in prices and their relationships, this evaluation needs constant updating. It was also found that the lack of financial support limited the interest in the cultivation of energy crops.

\section{CONCLUSIONS}

- The growing importance of economic assessment in agricultural research is a consequence of the transition to the market economy system in agriculture and the adoption, as the overriding objective, of the concept of sustainable development.

- The economic assessment allows selection and verification of organizational solutions, technology variants and farming systems from the point of view of the possibility of achieving economic goals. It contributes to the objectivity of evaluations formulated by agrotechnics.

- The possibilities and scope of economic evaluation in agricultural research are constantly expanding, covering new issues and research trends.

- Economic evaluation plays a complementary role in agricultural research and is aimed mainly at objectivization and support of solutions offered in agricultural practice.

- Strengthening the importance of this research requires closer cooperation with specialists in agrotechnology and zootechnics as well as respect of the existing methods of economic assessment and economic categories. It is also necessary to use IT systems and collect full, reliable, current data from farms and their surroundings.

\section{Acknowledgements}

The scientific paper was carried out as part of task 1.8 in the IUNG-PIB Multi-annual Program for the years 2016-2020.

\section{REFERENCES}

1. Adamowicz, M. (2006). Koncepcja trwałego i zrównoważonego rozwoju wobec wsi i rolnictwa [The concept of sustainable development with the reference to agricultural and rural areas]. Prace Naukowe. Szkoła Główna Gospodarstwa Wiejskiego. Wydział Ekonomiczno-Rolniczy. Katedra Polityki Agrarnej i Marketingu, 38, pp. 11-25.

2. GUS [Statistics Poland] (2018). Rocznik Statystyczny Rzeczypospolitej Polskiej 2018 [Statistical Yearbook of the Republic of Poland].

3. Harasim, A., Krasowicz, S., Matyka, M. (2014). Zróżnicowanie stopnia zrównoważenia rolnictwa w Polsce $\mathrm{w}$ ujęciu regionalnym [Differentiation in the degree of sustainable agriculture in Poland in a regional perspective]. Studia i Raporty IUNG-PIB, 40 (14), pp. 113-124.

4. IUNG-PIB [Institute of Soil Science and Plant Cultivation - State Research Institute in Puławy] (2010-2018). Sprawozdania z działalności instytutu [Reports on the Institute's activities]. IUNG, Puławy.

5. Krasowicz, S., Harasim, A. (2001). Problemy ekonomii i ekologii w badaniach rolniczych w latach 1981-2000 (na przykładzie IUNG) [Economic and ecological issues in agricultural research over the years 1981 (on the example of the IUNG)]. Roczniki Naukowe SERiA, 3 (6), pp. 7-10.

6. Manteuffel, R. (1981). Ekonomika i organizacja gospodarstwa rolniczego [Economics and organization of a farm]. PWRiL, Warszawa.

7. Nalborczyk, E. (2005). Rolnicza energetyka. Biomasa jako źródło ekologicznej energii. [Agricultural energy. Biomass as a source of ecological energy]. Academia, 3, pp. 16-19. 